Far Eastern Entomologist

\begin{tabular}{lll}
\hline Number 439: 29-32 & ISSN 1026-051X (print edition) & October 2021 \\
\hline
\end{tabular}

https://doi.org/10.25221/fee.439.4

http://zoobank.org/References/B3AB6AA8-B60B-4B97-8937-1231DDCC1337

\title{
FIRST RECORD OF XIPHIDIOPSIS (XIPHIDIOPSIS) SYMMETRICA GOROCHOV, 2011 (ORTHOPTERA: TETTIGONIIDAE: MECONEMATINAE) FROM CHINA
}

\author{
Li-Min Lu, Fu-Ming Shi ${ }^{*}$ \\ College of Life Sciences, Hebei University, Baoding 071002, P.R. China. \\ *Corresponding author, E-mail: shif_m@126.com
}

Summary. Xiphidiopsis (Xiphidiopsis) symmetrica Gorochov, 2011 is recorded from China (Guangxi and Yunnan provinces) for the first time. The description and photographs of Chinese specimens are also given. The studied material is deposited in the Museum of Hebei University, Baoding, China.

Key words: Tettigoniidae, Xiphidiopsis, fauna, first record, Guangxi, Yunnan, China.

Л. М. Лю, Ф. М. Ши. Первое указание Xiphidiopsis (Xiphidiopsis) symmetrica Gorochov, 2011 (Orthoptera: Tettigoniidae: Meconematinae) из Китая // Дальневосточный энтомолог. 2021. N 439. С. 29-32.

Резюме. Впервые для Китая (провинции Гуанси и Юннань) приводится Xiphidiopsis (Xiphidiopsis) symmetrica Gorochov, 2011. Также приведены описание и фотографии китайских экземпляров. Изученный материал хранится в музее Хэбэйского университета, Баодин, Китай.

\section{INTRODUCTION}

Redtenbacher (1891) established the genus Xiphidiopsis Redtenbacher, 1891, and assigned Xiphidiopsis fallax Redtenbacher, 1891 as type species. This genus consists of four subgenera and 79 species, of which 23 species occur in China and 19 species are endemic to China (Gorochov, 1993, 1998, 2011; Shi \& Zheng, 1995; Shi \& Chen, 2002; Shi \& Du, 2006; Wang et al., 2015; Han et al., 2015; Wang et al., 2019; Cui et al., 2020, Jin et al., 2020; Cigliano et al., 2021). Up to now, Xiphidiopsis (Xiphidiopsis) symmetrica Gorochov, 2011 was known by a single male (holotype) described from Northeast Vietnam (Gorochov, 2011). Nowadays this species is discovered from Guangxi and Yunnan provinces of China.

\section{NEW RECORD}

Xiphidiopsis (Xiphidiopsis) symmetrica Gorochov, 2011

Fig. 1

MATERIAL EXAMINED. China: Guangxi, Jinxiu, Shengtangshan, 13.VIII 2018, $1 \widehat{\jmath}$,

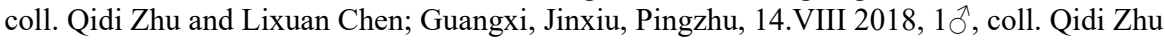


and Lixuan Chen; the same locality, 16.VIII 2019, 40, coll. Lixuan Chen and Lidan Zhang; the same locality, 16.VIII 2019, 10े, coll. Lixuan Chen and Xiang Zheng; Yunnan, Hekou, Yaoshanxiang, 11.IX 2020, 1今, coll. Qidi Zhu.

DESCRIPTION. Male from China. Body small. Fastigium verticis conical, apex slightly rounded, with a longitudinal sulcus on dorsal surface. Eyes semiglobular, protruding outwards. Apical segment of maxillary palpi slightly as long as subapical one, apex slightly swollen. Anterior margin of pronotum straight, posterior margin obtusely rounded; lateral lobe longer than deep and humeral sinus comparatively shallow (Fig. 1A-B). Thoracic auditory spiracles peanut-shaped, exposed.
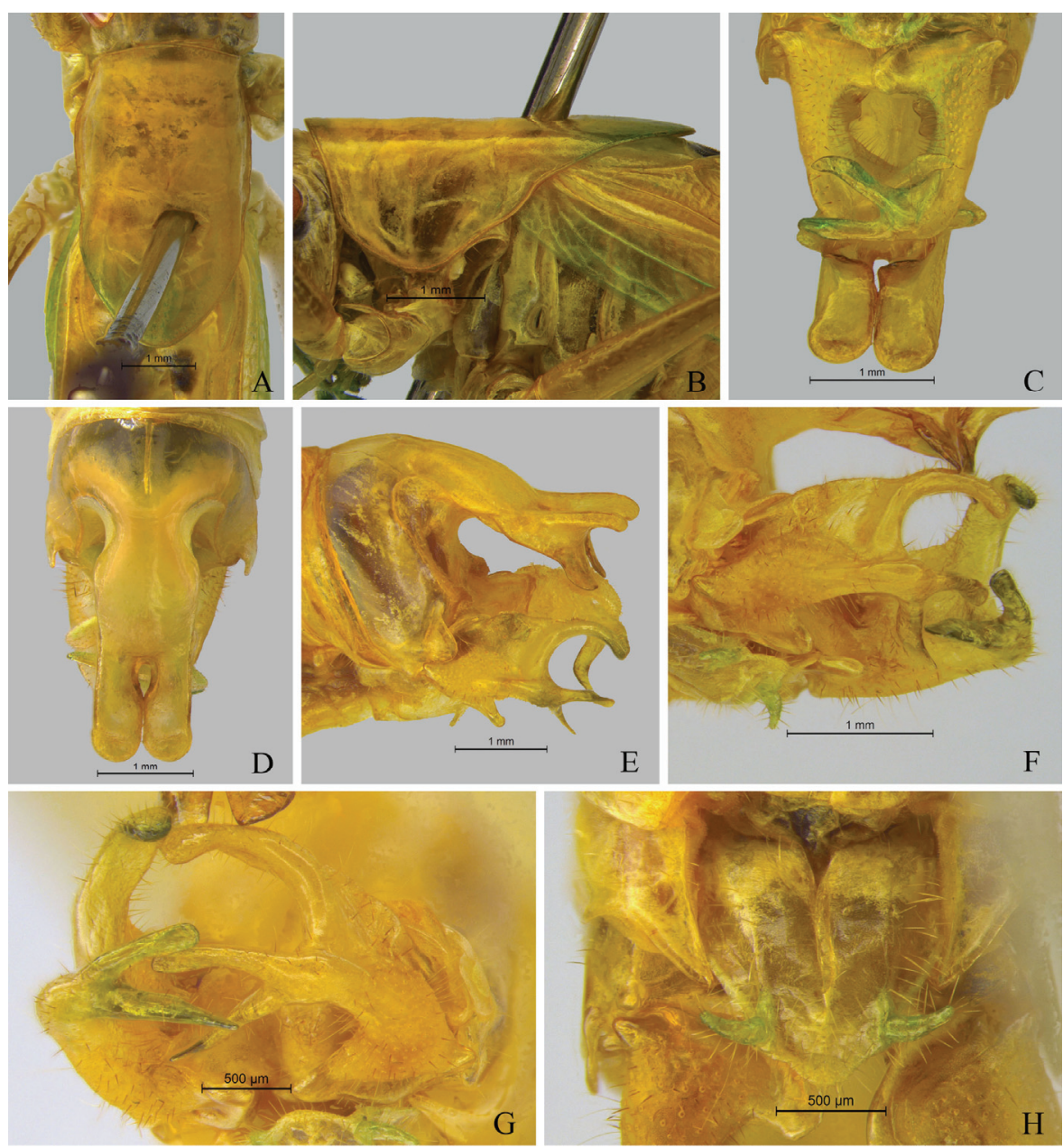

Fig 1. Xiphidiopsis symmetrica, male from China. A - pronotum, dorsal view; B - the same, lateral view; $\mathrm{C}$ - apex of abdomen, ventral view; D - the same, dorsal view; E - the same, lateral view; F - the same, latero-ventral view; $\mathrm{G}$ - the same, apical view; $\mathrm{H}$ subgenital plate, ventral view. 
All femora unarmed on ventral surfaces. Fore coxa with a long spine; fore tibiae with 4-6 long spines on inner side and 4-7 long spines on outer side of ventral surface; fore tibial tympana open on both sides. Middle tibiae with 3-4 long spines on inner and outer sides of ventral surface separately. Hind tibiae with 25-30 spines on inner margin and 26-30 spines on outer margin of dorsal surface, with 2 pairs of ventral apical spurs and 1 pair of dorsal apical spurs. Tegmina developed, surpassing apices of postfemora, apices rounded; hind wings longer than tegmina.

Tenth abdominal tergite with posterior margin concave (Fig. 1D), apices of lateral posterior margin slightly extended, trapezoid-shaped (Fig. 1E). Tenth abdominal tergite with a long, comparatively broad, symmetrical posterior process, which base of lateral margins slightly concave; the process slightly swell, apical half divided into 2 lateral lobes, apices obtusely rounded (Fig. 1D); every lateral lobe with a conical process on ventral surface, shorter than the lateral lobe, base broad and apex rounded (Fig. 1E). Cercus symmetric, base with a finshaped process on inner margin and a short conical process on outer margin of ventral surface, apex rounded (Fig. 1C); cercus with apex divided into 2 branches, dorsal branch slightly thin, moderately curved inward and backward, apex blunt (Fig. 1E-G); ventral branch divided into 2 branches, inner one approximately sickle-shaped, diluted, base broad and apex slightly acute; outer one finger-shaped, thin, apex slightly extended (Fig. 1C, 1F-G). Subgenital plate nearly triangular, base slightly broad, gradually narrowing, apex rounded; styli inserted on subapices of lateral margins of subgenital plate, conical. (Fig. 1H)

Female. Unknown.

COLORATION. Body light green. Eyes brown. Genicular lobes of hind femora with a black spot separately. Tegmina with sparse light brown spots, stridulatory field light brown.

MEASUREMENTS. Length (in $\mathrm{mm}$ ): body (from apex of fastigium verticis to posterior margin of tenth abdominal tergite): 12.0-15.0; pronotum: 4.0-4.4; tegmina: 19.0-19.6; postfemora: $10.0-13.0$.

DISTRIBUTION. China (new record): Guangxi and Yunnan provinces; Vietnam: Cao Bang province.

\section{ACKNOWLEDGEMENTS}

We are grateful to Dr. A. V. Gorochov (Russia) for checking the type specimen and all collectors for collecting the specimens. This project is supported by the National Natural Science Foundation of China $(31672259,31872268)$.

\section{REFERENCES}

Cigliano, M.M., Braun, H., Eades, D.C., \& Otte, D. 2021. Orthoptera Species File Online. Version 5.0/5.0. Available from: http://Orthoptera.SpeciesFile.org. (Accessed: 2 May 2021).

Cui, P., Liu, Q. \& Chang, Y.L. 2020. Two new species of the genus Xiphidiopsis Redtenbacher, 1891 (Tettigoniidae: Meconematinae: Meconematini) from Yunnan, China. Zootaxa, 4845(1): 127-132. DOI: https://doi.org/10.11646/zootaxa.4845.1.10

Gorochov, A.V. 1993. A contribution to the knowledge of the tribe Meconematini (Orthoptera: Tettigoniidae). Zoosystematica Rossica, 2(1): 63-92.

Gorochov, A.V. 1998. New and little known Meconematinae of the tribes Meconematini and Phlugidini (Orthoptera, Tettigoniidae). Zoosystematica Rossica, 7(1): 101-131.

Gorochov, A.V. 2011. Taxonomy of the katydids (Orthoptera: Tettigoniidae) from East Asia and adjacent islands. Communication 3. Far Eastern Entomologist, 236: 1-13. 
Han, L., Di, J.X., Chang, Y.L. \& Shi, F.M. 2015. Three new species of the genus Xiphidiopsis Redtenbacher, 1891 (Orthoptera: Tettigoniidae: Meconematinae) in China. Zootaxa, 4018(4): 553-562. DOI: https://doi.org/10.11646/zootaxa.4018.4.4

Jin, X.B., Liu, X.W. \& Wang, H.Q. 2020. New taxa of the tribe Meconematini from SouthPacific and Indo-Malayan Regions (Orthoptera, Tettigoniidae, Meconematinae). Zootaxa, 4772(1): 1-53. DOI: https://doi.org/10.11646/zootaxa.4772.1.1

Redtenbacher, J. 1891. Monographie der Conocephaliden. Verhandlungen der KaiserlichKöniglichen Zoologisch-Botanischen Gesellschaft in Wien, 41: 315-562.

Shi, F.M. \& Chen, H.M. 2002. Descriptions of two new species of Xiphidiopsis Redtenbacher (Orthoptera: Meconematidae) from Guizhou Province, China. Entomologia Sinica, 9(3): 69-72.

Shi, F.M. \& Du. X.C. 2006. Pseudophyllidae, Phaneropteridae, Mecopodidae, Meconematidae, Conocephalidae and Tettigoniidae. P. 115-129. In: Li, Z.Z. \& Jin, D.C. (Eds.). Insects from Fanjingshan Landscape. Guizhou Science and Technology Publishing House, Guiyang.

Shi, F.M. \& Zheng, Z.M. 1995. Descriptions of four new species of the genus Xiphidiopsis (Orthoptera: Tettigonioidea: Meconematidae). Entomotaxonomia, 17(3): 157-161.

Wang, H.Q., Liu, X.W. \& Li, K. 2015. New taxa of Meconematini (Orthoptera: Tettigoniidae: Meconematinae) from Guangxi, China. Zootaxa, 3941(4): 509-541. DOI: https://doi.org/ 10.11646/zootaxa.3941.4.3

Wang, T., Chen, P.W. \& Shi, F.M. 2019. Two new species of the tribe Meconematini (Orthoptera: Tettigoniidae: Meconematinae) from Taiwan. Zootaxa, 4564(1): 295-300. DOI: https://doi.org/10.11646/zootaxa.4564.1.13

(C) Far Eastern entomologist (Far East. entomol.) Journal published since October 1994. Editor-in-Chief: S.Yu. Storozhenko

Editorial Board: A.S. Lelej, S.A. Belokobylskij, M.G. Ponomarenko, V.A. Mutin, E.A. Beljaev, E.A. Makarchenko, A.V. Gorochov, T.M. Tiunova, M.Yu. Proshchalykin, S.A. Shabalin, V.M. Loktionov

Address: Federal Scientific Center of the East Asia Terrestrial Biodiversity (former Institute of Biology and Soil Science), Far East Branch of the Russian Academy of Sciences, 690022, Vladivostok-22, Russia.

E-mail: storozhenko@biosoil.ru web-site: http://www.biosoil.ru/fee 